\title{
Active learning in history teaching in higher education: The effect of inquiry-based learning and a student response system-based formative assessment in teacher training
}

\author{
Sergio Tirado-Olivares, Ramón Cózar-Gutiérrez, Rebeca García-Olivares, José Antonio González- \\ Calero \\ LabinTic: Lab of Technology Integration in Classrooms, Faculty of Education of Albacete, University of \\ Castilla-La Mancha, Spain
}

\begin{abstract}
Information and communication technology has produced changes in the demands of modern-day society (e.g., most jobs will require advanced digital skills in the short term). In addition, nowadays, new active methodologies using emerging technologies are being put into practice. However, little research has been conducted with pre-service teachers, particularly in the teaching of history. This quantitative study analysed the impact of the implementation of a mixed methodology using inquiry-based learning and a student response system (SRS) for the formative assessment of the academic achievement of 240 prospective primary teachers of history. The application of this mixed methodology shows better academic results than traditional lecture-based teaching. In addition, students' scores achieved through use of the SRS predicted the scores of male students in the final exam; however, this was not in the case for females.
\end{abstract}

\section{Implications for practice or policy:}

- The introduction of information and communication technology into history teaching brings active learning environments in higher education.

- Pre-service teachers can improve their knowledge of history through the implementation of inquiry-based learning methodology and SRSs.

- Our results indicate that an SRS can be an effective tool for teachers to carry out students' formative assessment.

- Teachers can effectively use SRS scores to predict male students' performance in history, but not female performance.

Keywords: history teaching, pre-service teachers, student response system, inquiry-based learning, quantitative

\section{Introduction}

The significance of information and communication technology (ICT) in society shows the need to introduce digital technology in the education sector (Gudmundsdottir et al., 2020). To meet the needs of the 21 st century, teachers have had to take on the responsibility of adapting their teaching methodologies (Marín-Suelves et al., 2018) by introducing technology in their teaching practices. However, this implementation requires not only technical knowledge but also pedagogical awareness (Cabero \& Barroso, 2016). Monteagudo Fernández et al. (2020) stated that the mere introduction of ICT in schools does not guarantee innovation, revealing that changes in the role of the teacher, the methodology and methods of assessment are needed. In particular, there is a need to train teachers in the use of ICT to develop their digital competence (Cabero \& Guerra, 2011; Gutiérrez et al., 2010). The level of teacher training and the difficulties the teachers encounter when implementing ICT prevent technology from becoming a resource of educative change and innovation (Colomer Rubio et al., 2018; Ramírez García \& González Fernández, 2016). Such is its impact that many countries in Europe now use ICT as a key element in teacher training (Gudmundsdottir et al., 2020). However, although digital competence is one of the main skills that should be promoted during pre-service teacher training, its acquisition is still a challenge in the educational field (Gudmundsdottiret al., 2020; Roblizo \& Cózar-Gutiérrez, 2015).

For many years, the traditional teaching methodology of lectures has been the source of classroom knowledge (Khalaf \& Zin, 2018). In social sciences, teachers convey the contents to the students, who are the recipients of the information. Related to this, authors such as Liceras and Romero (2016) and GómezCarrasco and Miralles-Martínez (2017) affirmed that history teaching has traditionally been based on the 
study and memorisation of contents. The students' passive role, along with excessive use of textbooks, has led to negative perceptions of and disinterest in learning history (Liceras \& Romero, 2016). On the other hand, Barton and Levstik (2004) argued that, although no one likes the way history is currently taught in schools, different studies criticise teachers for their teaching methods; teachers, in turn, blame the students for their apathy. However, new educational environments demand that pupils must be the centre of the teaching-learning process (Muntaner et al., 2020). The teacher must go from being the disseminator of knowledge to being a facilitator of learning; instead of giving direct instructions, teachers must encourage students to think about their own questions related to history, thus promoting the development of complex historical thinking (Gómez-Carrasco \& Miralles-Martínez, 2017; Seixas \& Morton, 2013; VanSledright, 2014). In this way, students assume an active role and build their own learning (Friesen \& Scott, 2013), developing their competence of learning to learn.

Hence, this study aimed to investigate the implementation of active methodologies using ICT in the specific field of history. In particular, the study evaluated pre-service teachers' learning of history contents, promoted by an inquiry-based-learning (IBL) methodology coupled with the use of a student response system (SRS), in comparison with a traditional methodology based on lecturing. In addition, the study analysed the potential of an SRS to offer formative assessment.

\section{Literature review}

\section{An active methodology: The case of IBL with ICT}

Among active educational methodologies, IBL is gaining popularity. IBL is an educational strategy where students are active learners who construct their own knowledge through the application of problem-solving skills (Pedaste et al., 2015). IBL enhances students' curiosity, exploration and experiential learning. Students answer the research questions through their own exploration and investigation, as well as through collaboration with their peers (Blessinger \& Carfora, 2014). IBL involves similar steps to those in the method used by historians (Gómez-Carrasco \& Miralles-Martínez, 2016): formulation, question and problem identification, investigation, data collection and analysis, conclusions development and disclosure of results. Therefore, IBL differs from common teaching practices carried out in the development of the awareness of history (Gómez-Carrasco et al., 2020). Nevertheless, there is not much research available on how prospective teachers can be prepared to organise IBL activities in history teaching (Voet \& De Wever, 2017).

According to Kori et al. (2014), technology-enhanced learning environments promote inquiry learning, as students' knowledge and skills are developed with the help of teachers or other learning means, such as technological tools. The introduction of ICT in the teaching of geography, history and other social sciences has brought about advantages in learning, such as self-regulated, individualised and meaningful learning, along with collaboration both between students and between teachers and students (Miralles-Martínez et al., 2019). Pertegal-Felices et al. (2020) carried out a study with students studying for a bachelor's degree in primary education with a minor in history, culture and heritage. They observed that ICT is a very useful tool for students and influential on their learning as it has the ability to teach and entertain. Similarly, Miralles-Martínez et al.'s (2013) study within the field of social sciences in teacher training verified how the introduction of ICT projects improved not only curriculum knowledge but also competences such as a critical attitude while searching for information. However, although there has been an insistence on the need to include ICT in the classroom to improve the teaching of the social sciences (Gómez-Carrasco et al., 2020), Ramírez García and González Fernández (2016) argued that the real transfer of ICT to the teaching-learning process is not really appreciated in most schools. The reluctance of teaching staff towards its use, due to their lack of training, results in little use of ICT in the learning processes and a lack of improvement in history education (Monteagudo Fernández et al., 2020).

Currently, there are few studies in which new technologies play an essential role in social science education. This is partly driven by the idea that history is at a disadvantage in contrast to experimental sciences because of the impossibility of reproducing historical events (Acosta Barros, 2010). For this reason, to refute the generalised idea of the traditional teaching of historical knowledge, further studies on the use of active learning methodologies, with the use of technology in social sciences, are necessary (Gómez-Carrasco et al., 2020). In this way, creating a theoretical framework solving the pre-service teachers' training needs is encouraged and, therefore, history education can be improved (Miralles-Martínez et al., 2019). 


\section{SRS: Setting the class in a playful context}

In pursuit of active-ludic methodologies that meet current teaching demands, gamification has experienced a substantial growth in popularity over recent years (Bai et al., 2020; Murillo-Zamorano et al., 2021). While it is true that there are many definitions of what gamification is, one of the most widespread is the one proposed by Kapp (2012), which includes the integration of characteristics, mechanics and aesthetics of games into non-playful contexts with the main purpose of engaging the participants. Studies have shown that games are considered effective pedagogical resources as they promote the acquisition of contents, motivation and critical thinking (Martínez-Navarro 2017; Talan et al., 2020). The breadth of the term gamification meant that it was necessary to be more specific about this methodology. Thus, Marczewski (2013) distinguished between "thin layer gamification" (understood as the use of some components of games such as points, badges and leaderboards) and "deep level gamification" (in which more complex components, dynamics and mechanics from games are involved to achieve higher engagement and intrinsic motivation). Therefore, given the general lack of interest in the study of social sciences (Liceras \& Romero, 2016), gamification can offer a viable alternative to turn the classroom into a dynamic and playful environment.

Subhash and Cudney's (2018) systematic revision of game-based learning encouraged using and exploring gamified learning and teaching systems to improve students' engagement, motivation and performance in higher education. In this way, the integration of gamified elements within the IBL methodology is simple but was a priority with regard to our study objectives. As Kapp (2012) underlined, the importance of gamification lies in the search for a specific objective, which in turn allows us to analyse how learning is taking place (Zichermann \& Cunningham, 2011). Furthermore, this playful educational context allows the implementation of methodologies based on cooperation and problem-solving in the classroom (DíazCruzado \& Troyano-Rodríguez, 2013; Jagušt et al., 2018). Therefore, gamification offers an attractive and motivating game space to students and seeks to stimulate their participation through attaining achievement or receiving rewards, but its implementation must always be linked to the goals and didactic objectives set (Rivero, 2017).

\section{How to assess history knowledge: From a summative assessment perspective to a formative one}

Kahoot! is an SRS that enables the creation of multiple-choice questionaries to assess in a playful way the learning acquired (Marín-Suelves et al., 2018; Tan et al., 2018). Studies have shown the potential of this application in teaching and learning in higher education, as it not only induces motivation and engagement but also promotes learning and knowledge reinforcement (Tan et al., 2018). Martínez-Navarro (2017) stated that the usefulness of Kahoot! lies in the fact that it can be incorporated into a teaching unit, achieving better learning results compared to a traditional expository methodology. Moreover, Cózar-Gutiérrez and Caparrós (2020) verified that the implementation of an SRS, such as Kahoot!, in the field of social sciences not only improves the learning process and motivation of students but also provides an instrument for the formative assessment of students.

Several studies have proved Kahoot!'s efficacy in higher education. Fuster-Guilló et al.'s (2019) study with undergraduate computer engineering students proved that the introduction of Kahoot! into theoretical lessons led to better academic performance and positive students' attitudes and perceptions towards learning. Students stated that Kahoot! helped them to reinforce what they had learned and that they felt more motivated to learn. They considered it necessary and essential in their academic performance. Likewise, in line with Wang et al. (2016)'s findings, Tan et al. (2018) found that Kahoot! improved the intrinsic and extrinsic motivation of students in a bachelor's degree in English for media. Moreover, the students highlighted that Kahoot! not only helped them to learn some things they missed during the lessons but it also significantly contributed to knowledge reinforcement and retention. Therefore, it seems that, in general, students positively value this type of SRS (Pertegal-Felices et al., 2020).

Moreover, Carrasco-Hernández et al. (2020) showed that students who used self-assessment tools like Kahoot! scored better in the final exam than those who did not. Related to this, Tóth et al. (2019) observed that students in an undergraduate degree in social sciences who completed Kahoot! quizzes weekly achieved better overall results. Ruíz Giménez et al. (2019) found that students in three bachelor degrees related to social science improved their learning, participated more in the subject, usually attended class 
and their interest and motivation increased. In addition, many students positively valued the immediate feedback received, which helped them to be aware of their mistakes and the correct answers.

Focusing on the benefits of implementing an SRS in the learning process, it seems that Kahoot! could be used for formative assessment (Orhan Göksün \& Gürsoy, 2019). Its instantaneous and continuous feedback is a key component in the evaluation process (Delacruz, 2011). The real-time answers of students provides information about their learning process (Shute, 2011) and the students are aware of their achievements, strengthening their learning outcomes (Fotaris et al., 2016). Students develop self-regulation abilities to manage their learning process, such as self-assessment, time management, progress monitoring, strategy use, intrinsic motivation and positive attitudes towards feedback, which leads to higher achievement (Clark, 2012). Similar results were observed in the systematic review on formative assessment carried out by McLaughlin and Yan (2017), who found that formative assessment led to better achievement scores and the development of complex cognitive processes, such as self-regulation, in students. For example, Angus and Watson (2009) found that student achievement on summative exams, as well as their overall learning, improved through the implementation of online formative assessment; similarly, Kibble (2007) demonstrated that quizzes were a rewarding learning tool which helped students be aware of their weaknesses in knowledge and increased their motivation to study for summative assessments. Concerning the assessment of history contents, Moreno-Vera et al. (2020) warned of the need to find alternative ways of assessment beyond the traditional final exam in which students have to convey memorised contents.

According to literature, history contents has been traditionally evaluated thanks to summative evaluative systems such as written tests, which involve a high cost in terms of time; however, they do not allow continuous or formative student assessment (Miralles-Martínez \& Gómez-Carrasco, 2014). For this reason, educational innovation should take into account the renewal of the evaluation process. These must be integrated into the learning process as one more task, allowing continuous feedback on the learning process for both teachers and students (Miralles et al., 2016). Consequently, evaluation instruments need to be adapted to the new educative demands (Moreno-Vera et al., 2020) allowing students to show that they have acquired active, relevant and contextualised learning (Sabido-Codina \& Albert Tarragona, 2020). Therefore, taking into account the benefits of integrating formative assessment into higher education (McLaughlin \& Yan, 2017) and in order to answer the identified needs in history assessment, further research is required.

\section{The acceptance of technology in the learning process in terms of gender}

Finally, it is important to consider how technology influences the learning process in terms of gender differences and academic performance. Concerning gender, Moya et al. (2011) stated that males seem to have more knowledge and skills concerning the use of ICT than females, who show less confidence and interest in technology.

Related to this, Carrasco-Hernández et al. (2020) observed that after using Kahoot! with undergraduate students of labour relations and human resources, males achieved better scores in the final exam, suggesting a relationship with higher ICT use by males. Reports from the International Computer and Information Literacy Study (Punter et al., 2017) found that while females use ICT mainly for communication and social networking, males use ICT for gaming and leisure (Cussó-Calabuig et al., 2017). As a result, a different approach to technology can be observed between males and females (Punter et al., 2017). Nonetheless, Cózar-Gutiérrez et al.'s, (2016) study showed that generalisation in the use of technologies allows the gradual elimination of this gender gap; moreover, higher scores related to knowledge and skills in technology are found among females. Therefore, the discrepancies found in the conclusions described in these studies demonstrate the need for further research in this field.

It seems that, depending on the nature of the subject and the way it is approached, the use of technology can have a positive or negative impact on student performance (García-Martín \& Cantón-Mayo, 2019; Torres-Díaz et al., 2016). For example, García-Martín and Cantón-Mayo (2019) established that Secondary Education female students outperformed male students in linguistics using ICT, which could be related to the higher development of communicative skills in females; Meggiolaro (2018) also observed gender differences between secondary education students in mathematics with the use of ICT. However, male students outperformed females in computer gaming activities and information management and technical 
operations. These results suggest that the different perceptions of and preferences for ICT use between males and females influence the learning performance (Meggiolaro, 2018).

In the field of higher education, despite the fact that males seem to have greater technical skills, more experience and knowledge in these technologies, González-Peiteado and Pino-Juste (2014) discovered that male students feel more comfortable with traditional learning styles, while females prefer more active learning styles and are willing to be trained on them. Females stand out as being more interested in using ICT for learning and in their own training (Gómez-Carrasco et al., 2020). Clearly, the aforementioned studies considered that females have a more favourable attitude towards the use of innovative methodologies for the teaching of history, especially in items related to the use of ICT. However, there is a scarcity of research concerning gender differences related to social science students' performance with the use of ICT.

Therefore, given the limited and heterogeneous results within the educational field of teacher training in history and taking into account that the combination of ICT with IBL may give rise to new learning environments, this research aimed to examine the effect of its implementation on pre-service primary teachers' academic achievement. To this end, we conducted a quantitative analysis to analyse the effectiveness of the intervention in terms of participants' learning gain. In addition, we also evaluated the role of student response systems as an assessment tool by analysing the association between participants' scores during the intervention gathered with these tools and their scores after the intervention. With all this, we intend to offer new evidence to the educational community about the implications for teaching practices that this instructional approach may have in future years. Thus, the objectives of the study were as follows:

(1) Evaluate eventual differences in the learning scores of pre-service teachers depending on the type of learning methodology (expository vs inquiry) and gender.

(2) Assess the predictive potential of SRS-based formative assessment on the academic achievement of university students in history depending on gender.

\section{Materials and methods}

\section{Participants}

A total of 240 pre-service teachers from a Spanish university participated in the study. All the participants were taking a subject titled Social Science II: History and its didactics. This subject consists of history contents established in the Spanish curriculum for primary education, as well as how to teach it. The students were divided into two groups. The first group consisted of 111 students ( 81 females and 30 males). This group was randomly chosen as the control group (hereinafter, CG). The intervention took place with the second group (IG), which consisted of 129 students (74 females and 55 males). Both groups came from the Faculty of Education and were taught by the same lecturer. In addition, the study complied with the American Psychological Association ethical standards in the treatment of the samples.

\section{Design}

To analyse the established objectives, we carried out a quasi-experimental study using a quantitative methodology. Therefore, we intended to discover how the implementation of an active IBL methodology affects the academic achievement of male and female students and how digital applications, such as Kahoot!, the discovery of how the learning process occurs.

\section{Procedure}

The experimental phase consisted of ten sessions lasting 60 minutes each. The procedure followed during the research is shown in Figure 1. In each CG session, the traditional lecture-based teaching was used. The lecturer gave lessons to the students and used PowerPoint presentations as visual supports. In this classroom setting, the lecturer plays a central role, while the students are passive listeners as this methodology does not promote student interactions (Miller et al., 2013). However, the IG sessions started with open-ended questions proposed by the lecturer, which oriented the learning objectives of each lesson. These questions 
helped students to understand what information they needed to find. Then, in each session, the students searched online for information related to the different questions.

In this way, both the IBL methodology, using an SRS and the key competence, learning to learn, were fostered in the IG. Students become responsible for their learning process as they adopt an active role, collecting the data needed to answer the questions posed (Friesen \& Scott, 2013). During the sessions, the lecturer's role in the IG group was to oversee the learning process. After this, during the last few minutes of each session, the use of Kahoot! enabled the lecturer to gather information about the students' learning . To this effect, the lecturer prepared a short Kahoot! quiz emphasising the most relevant content that the students should have worked on during the session.

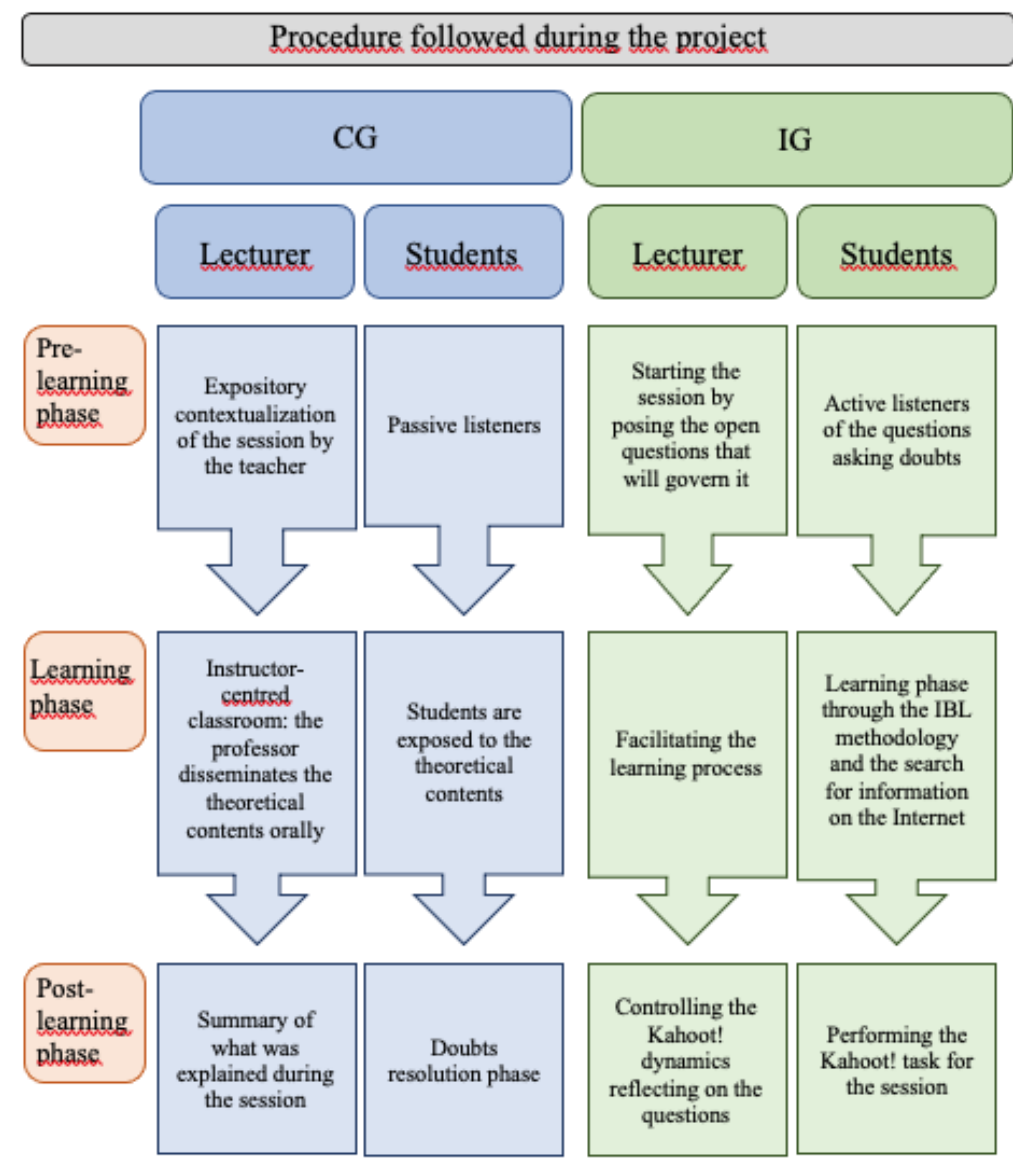

Figure 1. Pedagogical dynamic implemented during each session in both groups Note. CG (Control Group), IG (Intervention Group)

After the intervention, both groups of students took the final exam. The scores of both groups were contrasted by gender. Moreover, since the SRS provides scores after each activity, we analysed these students' scores amongst the IG students, too.

\section{Instruments and measurements}

Student learning was evaluated for both groups through a final exam at the end of the intervention. This approach, established from the comparison between the two groups, means that the benefits of the methodology used in the IG compared to the CG could be verified. The final exam was an ad hoc test made up of 15 multiple- choice questions. We specially designed it to measure the academic achievement attained by the students in relation to the contents worked on in both groups. Furthermore, in relation to the second objective of the research, to provide continuous feedback of the academic performance of the IG students, the scores obtained by the SRS-based formative assessments of all the participants in the different tasks during the project were used. In particular, the IG students performed nine different tasks. The curriculum contents of each task were sequenced based on the content worked on during the session. 


\section{Statistical analysis}

All the data collected were exported to a database for analysis using SPSS version 24 software. After that, all the learning scores (correct answers in the final exam and SRS scores) were standardised on a 10-point scale. Finally, different descriptive and inferential statistical analyses were carried out - all of them with an alpha level of .05 .

In relation to the first objective, a two-way ANOVA test was used to find out if intervention and gender influence the participants' learning scores. Moreover, in relation to the second objective, a simple lineal regression using the SRS scores to model learning scores was carried out.

\section{Results}

The results obtained have been divided into sections corresponding to each objective. The first analysis was done to contrast the two methodologies implemented, based on the academic achievement attained by the students. The second analysis intended to evaluate the association between SRS-based scores and exam scores. Both analyses were compared by gender.

\section{Differences in academic achievement depending on the methodology}

The descriptive statistical data are shown in Table 1. As can be seen, both the female and male students had higher scores with the introduction of the SRS and the IBL methodology compared to students who attended traditional lectures. To evaluate the statistical effect of this difference, an inferential analysis was performed through a two-way ANOVA to examine the effect of gender and methodology on academic performance.

Table 1

Descriptive statistical data according to methodology and gender

\begin{tabular}{lccc}
\hline \multicolumn{1}{c}{$n$} & $M$ & $S D$ \\
\hline Males & & & \\
$\quad$ Females & 30 & 6.40 & 1.83 \\
IG & 81 & 6.07 & 1.89 \\
$\quad$ Males & 55 & 7.78 & \\
$\quad$ Females & 74 & 7.62 & 1.55 \\
\hline
\end{tabular}

As can be seen in Table 2, there was no statistically significant interaction between the effects of gender and methodology. However, the ANOVA test revealed a significant difference between groups. Nevertheless, there was no statistically significant difference in terms of gender. To verify the effect size of the methodology, the partial eta-squared $\left(\eta^{2}\right)$ was used: $\eta^{2}=.134$. According to Cohen (1988), this value corresponds to a medium-large effect. Therefore, regardless of gender, the academic achievement of prospective teachers in the IG is greater compared to the results obtained in the CG. These results support the efficacy of the combined use of the IBL methodology and the SRS-based formative assessment. This higher academic performance, regardless of gender, can be seen in Figure 2.

Table 2

Two-way ANOVA results using gender and methodology to examine the effect on academic performance.

\begin{tabular}{lllllll}
\hline Predictor & Sum of squares & $d f$ & Mean square & $F$ & $p$ & $\eta^{2}$ \\
\hline Methodology & 110.91 & 1 & 110.91 & 36.64 & $<.001$ & .134 \\
Gender & 3.05 & 1 & 3.05 & 1.01 & .316 & .004 \\
Methodology*Gender & .36 & 1 & .36 & .12 & .732 & .000 \\
Error & 714.43 & 236 & 3.03 & & & \\
\hline Total & 12560.89 & 240 & & & &
\end{tabular}




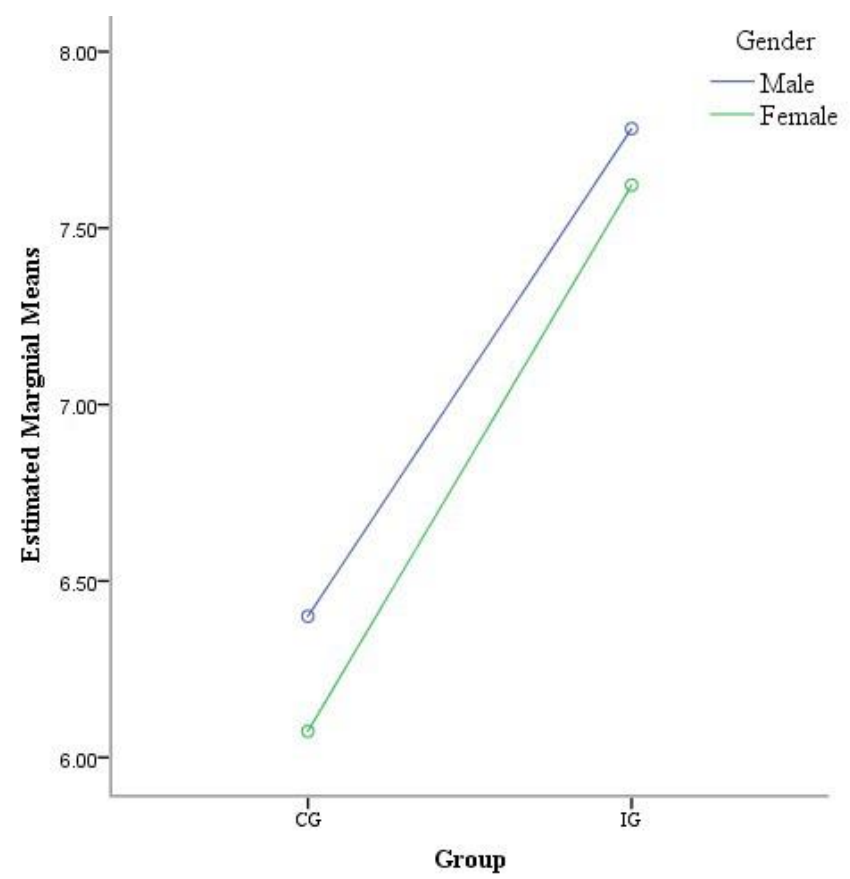

Figure 2. Interaction plot-academic achievement by male and female students in the CG compared to the $I G$

\section{Potential of SRS scores in predicting academic achievement}

To check the feasibility of using SRS as a formative assessment tool, a simple lineal regression model was calculated to predict student academic achievement in the final exam, based on the SRS scores. For this analysis, we selected all the students from the IG who participated in at least in half of the lessons during the project. In particular, in this case, the sample was made up of 122 students (71 females and 51 males). The linear regression model with all the participants from the IG (males and females) was not statistically significant: $F(1,120)=3.91 ; p=.0503$. These results, so close to statistical significance, reinforce the need for a more in-depth analysis according to gender.

In the case of males, a significant regression equation was found: $F(1,49)=10.13 ; p=.003$. However, this was not found among females $F(1,69)=.15 ; p=.699$. Therefore, we can state that while SRS scores can predict the academic achievement of male students, this does not happen in the case of female students. The results obtained from amongst the female students suggest that there is no predictive factor of academic performance at the general level without taking into consideration the gender variable (without making distinction by gender). Moreover, the r-squared $\left(R^{2}\right)$ achieved considering only male students shows a proportion of variance in the final exam scores of .17; the $r$ value being equal to .41. Miles (2014) emphasised that, in a linear regression with one predictor, the square of the correlation coefficient is equal to r-squared. In this way, $r$ value can be considered to indicate the fit of the value. Thus, according to Cohen (1988), the value obtained in our case can be considered a medium effect. Finally, the regression coefficient achieved in the case of males indicates that an increase in one point in the mean SRS score corresponded, on average, to an increase in the final exam score of .43 (Table 3 ).

Table 3

Regression analysis summary for SRS predicting academic achievement in history

\begin{tabular}{lllllll}
\hline & & $B$ & $S D$ & Beta & $t$ & $p$ \\
\hline Male & Constant & 5.18 & .90 & & 5.78 & $<.001$ \\
& Average SRS scores & .43 & .13 & .41 & 3.18 & .003 \\
\multirow{2}{*}{ Female } & Constant & 8.12 & 1.16 & & 6.97 & $<.001$ \\
& Average SRS scores & -0.07 & 0.19 & -0.05 & -0.39 & 0.699 \\
\hline
\end{tabular}


Finally, to contrast the results in the regressions equations obtained, we decided to follow the same procedure - that is, we considered only those students who had performed all the tasks. The sample size was reduced to 37 students ( 15 males and 22 females). Contrary to what happened in the previous case, the general linear regression (considering both genders) reported a significant value: $F(1,35)=6.41 ; p=.016$, with an $R^{2}$ of $.16(r=.39)$. In addition, in the analysis differentiating by gender, similar results to the previous analysis were reached: in the case of males, a significant regression equation: $F(1,13)=15.69 ; p$ $=.0016$, with an $R^{2}$ of $.55(r=.74)$. The value obtained indicates that an increase in one point in the SRS scores corresponded, on average, to an increase in the learning score of .69. However, non-significant results were found among females $F(1,20)=.012 ; p=.915$.

\section{Discussion}

The results provide evidence that the methodological approach used in the IG is more effective than the CG methodology. Hence, according to the first objective of the investigation, we can conclude that the implementation of the IBL methodology and the SRS-based formative assessment improves the students' knowledge level. These results allow us to draw conclusions similar to those obtained in other academical fields concerning the use of active methodologies (Blasco-Serrano et al., 2018; Friesen \& Scott, 2013; Gómez-Carrasco et al., 2019), concerning the use of IBL in particular (Kori et al., 2014) and the use of new technological tools within the teaching-learning process (Cózar-Gutiérrez et al., 2019; Miralles-Martínez et al., 2013; Murillo-Zamorano et al., 2021; Pertegal-Felices et al., 2020). According to these results, IBL seems to be an effective strategy in history learning. In this situation, memorisation is replaced by content reflection, which results in meaningful and significant learning. This is currently defended by authors such as Gómez-Carrasco et al. (2020), since the formation of historical consciousness requires a transformation of the present didactics of history, replacing traditional lecture methodologies with active learning methodologies, based on inquiry and the use of ICT.

In addition, the integration of technology into history learning with applications which enable the implementation of an SRS, such as Kahoot!, has improved the academic results of the students. In line with previous studies (Pertegal-Felices et al., 2020; Ruíz Giménez et al., 2019; Tan et al., 2018), our results highlight the potential of this application in teaching and learning in higher education, as it promotes motivation, engagement and learning reinforcement. Therefore, the combination of Inquiry-Based Learning with technological applications leads to new educational settings, where students adopt an active role in their learning process (San Martín et al., 2015).

Focusing on gender, some previous studies (Gómez-Carrasco et al., 2020; González-Peiteado \& Pino-Juste, 2014) considered that male students feel more comfortable with traditional learning styles, while females prefer more active learning styles. However, the inferential statistical analysis by the ANOVA test allows us to see that the implementation of the IBL methodology and the SRS-based formative assessment improve students' knowledge, independently of their gender. This conclusion, along with statements made by other authors that in higher education both male and female students have a positive attitude towards the integration of technology into learning and feel motivated by it ((Yau \& Cheng, 2012), makes us believe that this methodological approach can not only increase motivation towards the study of history but also produce greater academic results in this area.

Moreover, related to our second objective, in the search for new evaluative approaches of a formative nature, the SRS proposed is perceived as a helpful tool to recall contents taught during a class, as was stated by Fuster-Guilló et al. (2019) and Tan et al. (2018). The learning of data, facts, concepts and principles which can be easily memorised and understood by students should be the basis for learning abilities, skills, procedures and techniques typical of history (historical thinking) which enable better knowledge and understanding of the subject (Cózar-Gutiérrez \& Caparros, 2020). It seems that weekly participation in Kahoot! quizzes, at the end of each class, raises students' efficiency in the learning process (Tóth et al., 2019). The results obtained by Turan and Meral (2018) demonstrated that SRSs increased achievement and participation and decreased the students' test anxiety levels. However, in terms of their efficacy in predicting the academic achievement of students, the gender variable acquires an essential role. This study indicates that this assumption can only be made in the case of male students. The results show that there is a predictive relationship between male SRS scores and their grades in the final exam, but not in the case of females. It could be argued that these results are due to the fact that females are less interested and less confident in the use of ICTs compared to males, who seem to know more about ICTs and be more adept at 
their use (Moya et al., 2011). Also, the different perceptions of and preferences for ICT use between males and females could have influenced the learning performance of the students (Meggiolaro, 2018).

Moreover, as Carrasco-Hernández et al. (2020) stated, after using Kahoot!, males achieved better scores in the final exam, which appears to be related to higher ICT use by males. These results were also apparent in our research. Therefore, compared to the findings of González-Peiteado \& Pino-Juste (2014), who showed that male students feel more comfortable with traditional methodologies, while female prefer more active ones, our investigation shows that in the particular field of teacher training in history, this conclusion cannot be reached.

\section{Conclusions}

The teaching of history needs to adapt to the demands of modern-day society governed by new technologies (Gómez-Carrasco et al., 2020). Studies carried out by different researchers, such as Hernández Cardona (2011) and Rivero (2011), showed that the use of different technologies, such as virtual characters, interactivity or expository multimedia, strengthen the learning of geography and history contents (MirallesMartínez et al., 2013). As stated by Pardo-Cueva et al. (2020), the application of ICT leads to changes in the training process and increases academic performance; it promotes innovation and the appearance of new learning environments. However, few studies have been carried out using new technologies as an essential role, specifically in higher education (Subhash \& Cudney, 2018).

For this reason, the present study sought to compare a traditional lecture methodology with an innovative one, such as the IBL methodology and the implementation of an SRS using technological applications, such as Kahoot!. The results obtained suggest that traditional teaching and assessment practices in social and historical teaching need to give way to new strategies and methodological instruments (Miralles-Martínez et al., 2019). This conclusion is based on the significant improvement in the demonstration of knowledge in the IG, who participated in a pedagogical innovation.

In order to make this change possible, teachers, specifically pre-service teachers, need to be trained in the use of ICT. They need to learn how to introduce ICT to promote autonomous, creative and critical thinking (Miralles-Martínez et al., 2019). However, the current vision of college students concerning the advantages of using ICT varies greatly depending on the field of study and gender (García-Martín \& Cantón-Mayo, 2019; Torres-Díaz et al., 2016). Furthermore, related to this, there is no consensus in the literature concerning gender preferences. Moya et al.'s (2011) study found that males have better skills, which is why they prefer active methodologies. However, González-Peiteado and Pino-Juste (2014) arrived at opposing conclusions: they found that females prefer new pedagogical approaches and males prefer traditional ones. Hence, educational research needs more studies that can clarify these assumptions, especially with preservice teachers in the field of history, because of the scarcity of studies that deal with these hypotheses (Kaarakainen et al., 2018).

Despite the fact that gamification is widely used nowadays, it is not common either in the university context or in the teaching of social science subjects (Ruíz Giménez et al., 2019). For this reason, SRSs are not the focus of educational research in these areas. Nonetheless, the results obtained in our study evidence the need for further studies to analyse if a positive relationship exists between SRS scores and subject grades (Ruíz Giménez et al., 2019). Furthermore, the results show that while SRS scores predict final exam scores in the case of male students, this is not the case for female students.

\section{Proposals for future research}

During the research, new hypotheses arose that could lead to interesting results in the field of teaching history. Firstly, one of the most important limitations of this study is that the IBL methodology implemented, together with SRS-based formative assessment, has led to an improvement in the academic performance of prospective teachers. However, it is necessary to clearly identify which of these elements caused this effect or if it originated by the combination of both. Therefore, future studies should compare different settings for the experimental condition, making it possible, for example, to compare results from IBL methodology alone and from IBL coupled with the use of SRSs. The current study focused only on analysing the advantages in terms of learning gain. Thus, future studies could also explore students' 
motivation towards the methodologies and tools used. This aspect may be especially relevant considering that our sample consisted of pre-service teachers. In this case, their satisfaction as trainees could influence the possibility of employing these methodologies in their future professional practice.

In addition, it would be interesting to carry out further studies using complementary instruments that help researchers to assess students' acquisition of other skills, such as historical thinking (e.g., Gómez-Carrasco \& Miralles-Martínez, 2017; Seixas \& Morton, 2013; VanSledright, 2014). The instruments used in our study focused exclusively on the assessment of the learning of factual contents but were not designed to measure more complex skills.

Moreover, the analysis of students 'answers who performed all the tasks proposed by the SRS evidenced interesting results that would benefit from in-depth investigation. As the number of students who completed all the tasks was reduced, future studies with a larger sample could offer more emphatic results and resounding conclusions. This is something that, due to the lack of studies in this field, could be a starting point for new gamified formative assessment approaches.

\section{Acknowledgements}

This work was supported by the European Union through European Regional Development Funds (ERDFFEDER) and the Castilla-La Mancha Regional Administration under grant SBPLY/19/180501/000278 and by the University of Castilla-La Mancha under grant 2021-GRIN-31060.

\section{References}

Acosta Barros, L. (2010). La enseñanza-aprendizaje de la historia en bachillerato y las TIC: La introducción de la estrategia Webquest [The teaching-learning of history in baccalaureate and ICT: The introdcution of the Webquest strategy]. Clio: History and History Teaching, 36(8), 1-10. http://clio.rediris.es/n36/didactica/lmacosta_iehcan.pdf

Angus, S. D., \& Watson, J. (2009). Does regular online testing enhance student learning in the numerical sciences? Robust evidence from a large data set. British Journal of Educational Technology, 40(2), 255-272. https://doi.org/10.1111/j.1467-8535.2008.00916.x

Bai, S., Hew, K. F., \& Huang, B. (2020). Does gamification improve student learning outcome? Evidence from a meta-analysis and synthesis of qualitative data in educational contexts. Educational Research Review, 30, Article 100322. https://doi.org/10.1016/j.edurev.2020.100322

Barton, K., \& Levstik, L. (2004). Teaching history for the common good. Lawrence Erlbaum.

Blasco-Serrano, A. C., Lorenzo, J., \& Sarsa, J. (2018). Percepción de los estudiantes al 'invertir la clase' mediante el uso de redes sociales y sistemas de respuesta inmediata [Students' perception of flipped classroom through the use of social networks and classroom response systems]. Revista de Educación a Distancia (RED), 57(6), 1-19. https://doi.org/10.6018/red/57/6

Blessinger, P., \& Carfora, J. M. (2014). Inquiry-based learning for the arts, humanities, and social sciences: A conceptual and practical resource for educators. Emerald Group Publishing Limited.

Cabero, J., \& Barroso, J. (2016). Formación del profesorado en TIC: Una visión del modelo TPACK [Teacher training in ICT: A vision of the TPACK model]. Cultura y Educacion, 28(3), 633-663. https://doi.org/10.1080/11356405.2016.1203526

Cabero, J., \& Guerra, S. (2011). La alfabetización y formación en medios de comunicación en la formación inicial del profesorado [Literacy and media training in initial teacher training]. Educacion XX1, 14(1), 89-115. https://doi.org/10.5944/educxx1.14.1.264

Carrasco-Hernández, A. J., Lozano-Reina, G., Lucas-Pérez, M. E., Madrid-Garre, M. F., \& SánchezMarín, G. (2020). Developing new learning tools in the classroom: The Kahoot experience. Journal of Management and Business Education, 3(3), 214-235. https://doi.org/10.35564/jmbe.2020.0014

Clark, I. (2012). Formative assessment: Assessment is for self-regulated learning. Educational Psychology Review, 24(2), 205-249. https://doi.org/10.1007/s10648-011-9191-6

Cohen, J. (1988). Statistical power analysis for the behavioral sciences (2nd ed.). Erlbaum.

Colomer-Rubio, J. C., SáizSerrano, J., \& Bel-Martínez, J. C. (2018). Competencia digital en futuros docentes de Ciencias Sociales en Educación Primaria: análisis desde el modelo TPACK [Digital competence in future teachers of social sciences in primary education: Analysis from the TPACK model]. Educatio Siglo XXI, 36(1), 107-128. chttps://doi.org/10.1007/s10648-011-9191-6 
Cózar-Gutiérrez, R., \& Caparrós, F. de B. (2020). Tecnologías emergentes al servicio de la evaluación en la enseñanza de la Historia Moderna [Emerging technologies at the service of evaluation in the teaching of modern history]. In F. García, C. J. Gómez, R. Cózar, \& P. Martínez (Eds.), La Historia Moderna en la Enseñanza Secundaria. Ediciones de la Universidad de Castilla-La Mancha (pp. 255264). Ediciones de la Universidad de Castilla-La Mancha. c

Cózar Gutiérrez, R., González-Calero Somoza, J. A., Villena Taranilla, R., \& Merino Armero, J. M. (2019). Análisis de la motivación ante el uso de la realidad virtual en la enseñanza de la historia en futuros maestros [Analysis of motivation in the use of virtual reality in the teaching of history in future teachers]. Edutec: Revista Electrónica de Tecnología Educativa, 68, 1-14. https://doi.org/10.21556/edutec.2019.68.1315

Cózar-Gutiérrez, R., De Moya-Martínez, M. V, Hernández-Bravo, J. A., \& Hernández-Bravo, J. R. (2016). Conocimiento y Uso de las Tecnologías de la Información y las Comunicaciones (TIC) según el estilo de Aprendizaje de los Futuros Maestros [Knowledge and use of information and communication technologies (ICT) according to the learning style of future teachers]. Formación Universitaria, 9(6), 105-118. https://doi.org/10.4067/S0718-50062016000600010

Cussó-Calabuig, R., Farran, X. C., \& Bosch-Capblanch, X. (2017). Are boys and girls still digitally differentiated? The case of Catalonian teenagers. Journal of Information Technology Education: Research, 16(1), 411-435. https://doi.org/10.28945/3879

Delacruz, G. C. (2011). Games as formative assessment environments: Examining the impact of explanations of scoring and incentives on math learning, game performance, and help seeking (CRESST Report 796). University of California. https://cresst.org/publications/cresst-publication$\underline{3166 /}$

Díaz-Cruzado, J., \& Troyano-Rodríguez, Y. (2013). El potencial de la gamificación en el ámbito educativo [The potencial of gamification in education]. In III Jornadas de Innovación Docente. Innovación Educativa: Respuesta En Tiempos de Incertidumbre. Universidad de Sevilla. https://idus.us.es/handle/11441/59067

Fotaris, P., Mastoras, T., Leinfellner, R., \& Rosunally, Y. (2016). Climbing up the leaderboard: An empirical study of applying gamification techniques to a computer programming class. The Electronic Journal of E-Learning, 14(2), 94-110. https://academicpublishing.org/index.php/ejel/article/view/1747/1710

Friesen, S., \& Scott, D. (2013). Inquiry-based learning: A review of the research literature. Alberta Ministry of Education. https://galileo.org/focus-on-inquiry-lit-review.pdf

Fuster-Guilló, A., Pertegal-Felices, M. L., Jimeno-Morenilla, A., Azorín-López, J., Rico-Soliveres, M. L., \& Restrepo-Calle, F. (2019). Evaluating impact on motivation and academic performance of a gamebased learning experience using Kahoot. Frontiers in Psychology, 10, Article 2843. https://doi.org/10.3389/fpsyg.2019.02843

García-Martín, S., \& Cantón-Mayo, I. (2019). Uso de tecnologías y rendimiento académico en estudiantes adolescentes [Use of technologies and academic performance in adolescent students. Comunicar, 27(59), 73-81. https://doi.org/10.3916/C59-2019-07

Gómez-Carrasco, C. J., Chaparro Sainz, Á., Felices de la Fuente, M. del M., \& Cózar-Gutiérrez, R. (2020). Estrategias metodológicas y uso de recursos digitales para la enseñanza de la historia. Análisis de recuerdos y opiniones del profesorado en formación inicial [Methodological strategies and use of digital resources for teaching history: Analysis of memories and opinions of teachers in initial training]. Aula Abierta, 49(1), 65-74. https://doi.org/10.17811/rifie.49.1.2020.65-74

Gómez-Carrasco, C. J., \& Miralles-Martínez, P. (2016). Las competencias históricas en educación obligatoria: evaluación, estrategias basadas en la indagación, y argumentación de los estudiantes [Historical competences in compulsory education: Assessment, inquired based strategies, and students' argumentation]. Journal of New Approaches in Educational Research, 5(2), 130-136. https://doi.org/10.7821/naer.2016.7.172

Gómez-Carrasco, C. J., \& Miralles-Martínez, P. (2017). Los espejos de Clío. Usos y abusos de la Historia en el ámbito escolar [Clio's mirrors: Use and abuses of history in the school environment]. Silex.

Gómez-Carrasco, C. J., Monteagudo-Fernández, J., Moreno-Vera, J.-R., \& Sainz-Gómez, M. (2019). Effects of a gamification and flipped-classroom program for teachers in training on motivation and learning perception. Education Sciences, 9(4), Article 299. https://doi.org/10.3390/educsci9040299

González-Peiteado, M., \& Pino-Juste, M. (2014). Aproximación a las representaciones y creencias del alumnado de magisterio sobre los estilos de enseñanza [Approach to the representations and beliefs of teaching students about teaching styles]. Educacion XX1, 17(1), 83-109.

https://doi.org/10.5944/educxx1.17.1.10706 
Gudmundsdottir, G. B., Gassó, H., Rubio, J. C., \& Hatlevik, O. E. (2020). Student teachers' responsible use of ICT: Examining two samples in Spain and Norway. Computers and Education, 152, Article 103877. https://doi.org/10.1016/j.compedu.2020.103877

Gutiérrez, A., Palacios, A., \& Torrego, L. (2010). La formación de los futuros maestros y la integración de las TIC en la educación: Anatomía de un desencuentro [The training of future teachers and the integration of ICT in education: Anatomy of a disagreement]. Revista de Educacion, 353(1), 267-293. http://www.revistaeducacion.educacion.es/re352/re352 TIC.pdf

Hernández Cardona, F. X. (2011). La iconografía en la didáctica de las ciencias sociales [Iconography in the didactics of social sciences]. Íber. Didáctica de Las Ciencias Sociales, Geografía e Historia., 68, 7-16. https://www.grao.com/es/producto/la-iconografia-en-la-didactica-de-las-ciencias-sociales

Jagušt, T., Botički, I., \& So, H. J. (2018). Examining competitive, collaborative and adaptive gamification in young learners' math learning. Computers \& Education, 125, 444-457. https://doi.org/10.1016/j.compedu.2018.06.022

Kaarakainen, M. T., Kivinen, O., \& Vainio, T. (2018). Performance-based testing for ICT skills assessing: A case study of students and teachers' ICT skills in Finnish schools. Universal Access in the Information Society, 17(2), 349-360. https://doi.org/10.1007/s10209-017-0553-9

Kapp, K. (2012). The gamification of learning and instruction: Game-based methods and strategies for training and education. John Wiley \& Sons.

Khalaf, B. K., \& Zin, Z. B. M. (2018). Traditional and inquiry-based learning pedagogy: A systematic critical review. International Journal of Instruction, 11(4), 545-564. https://doi.org/10.12973/iji.2018.11434a

Kibble, J. (2007). Use of unsupervised online quizzes as formative assessment in a medical physiology course: Effects of incentives on student participation and performance. American Journal of Physiology - Advances in Physiology Education, 31(3), 253-260. https://doi.org/10.1152/advan.00027.2007

Kori, K., Mäeots, M., \& Pedaste, M. (2014). Guided reflection to support quality of reflection and inquiry in web-based learning. Procedia - Social and Behavioral Sciences, 112, 242-251. https://doi.org/10.1016/j.sbspro.2014.01.1161

Liceras, Á., \& Romero, G. (2016). Didáctica de las Ciencias Sociales Fundamentos, contextos y propuestas [Teaching social sciences: Foundations, contexts and proposals]. Pirámide.

Marín-Suelves, D., Vidal-Esteve, M. I., Peirats-Chacón, J., \& López-Marí, M. (2018). Gamificación en la evaluación del aprendizaje: valoración del uso de Kahoot! [Gamification in the assessment of learning: Assessment of the use of Kahoot!] In REDINE (Eds.), Innovative strategies for higher education in Spain (pp. 8-17). Adaya Press. https://www.adayapress.com/wpcontent/uploads/2018/04/ched2.pdf

Marczewski, A. (2013). Gamification: A simple introduction.

Martínez-Navarro, G. (2017). Tecnologías y nuevas tendencias en educación: aprender jugando. El caso de Kahoot [Technologies and new trends in education: Learning by playing: Kahoot! case]. Opción: Revista de Ciencias Humanas y Sociales, 33(83), 252-277. https://produccioncientificaluz.org/index.php/opcion/article/view/23116

McLaughlin, T., \& Yan, Z. (2017). Diverse delivery methods and strong psychological benefits: A review of online formative assessment. Journal of Computer Assisted Learning, 33(6), 562-574. https://doi.org/10.1111/jcal.12200

Meggiolaro, S. (2018). Information and communication technologies use, gender and mathematics achievement: Evidence from Italy. Social Psychology of Education, 21(2), 497-516. https://doi.org/10.1007/s11218-017-9425-7

Miles, J. (2014). R-squared, adjusted R-squared. Encyclopedia of statistics in behavioral science. In N. Balakrishnan, T. Colton, B. Everitt, W. Piegorsch, F. Ruggeri, \& J. L. Teugels (Eds.), Wiley StatsRef: Statistics reference online. John Wiley \& Sons, Ltd. https://doi.org/10.1002/9781118445112.stat06627

Miller, C. J., McNear, J., \& Metz, M. J. (2013). A comparison of traditional and engaging lecture methods in a large, professional-level course. American Journal of Physiology - Advances in Physiology Education, 37(4), 347-355. https://doi.org/10.1152/advan.00050.2013

Miralles-Martínez, P., \& Gómez-Carrasco, C. J. (2014). Dime qué preguntas y te diré qué evalúas y enseñas. Análisis de los exámenes de ciencias sociales en tercer ciclo de Educación Primaria [Tell me what you ask and I will tell you what you evaluate and teach: Analysis of the social sciences exams in the thirdh cycle of primary education]. Aula Abierta, 42(2), 83-89.

https://doi.org/10.1016/j.aula.2014.05.002 
Miralles-Martínez, P., Gómez-Carrasco, C. J., \& Arias Ferrer, L. (2013). La enseñanza de las ciencias sociales y el tratamiento de la información. Una experiencia con el uso de webquests en la formación del profesorado de educación primaria [The teaching of social sciences and information processing: An experiences with the use of webquests in the training of primary education teachers]. RUSC Universities and Knowledge Society Journal, 10(2), 344-357. https://doi.org/10.7238/rusc.v10i2.1536

Miralles-Martínez, P., Gómez-Carrasco, C. J., \& Monteagudo Fernández, J. (2019). Percepciones sobre el uso de recursos TIC y «MASS-MEDIA»Para la enseñanza de la historia. Un estudio comparativo en futuros docentes de España-Inglaterra [Perceptions on the use of ICT resources and "mass-media" for the teaching of history: A comparative study of future teachers in Spain-England]. Educación XX1, 22(2). https://doi.org/10.5944/educxx1.21377

Miralles, P., Molina, J., \& Trigueros, J. (2016). Diálogos de evaluación en la educación secundaria obligatoria: escenarios, protagonistas y estado actual de la investigación en Ciencias Sociales, Geografía e Historia [Assessment dialogues in compulsory secondary education: Scenarios, protagonists and current state of research in social sciences, geoography and history]. In M. L. S. Szymanski (Ed.), Sentidos e desafios da avaliaçao educacional (pp. 105-138). Universidade Estadual do Oeste do Paraná.

Monteagudo Fernández, J., Rodríguez Pérez, R. A., Escribano-Miralles, A., \& Rodríguez García, A. M. (2020). Percepciones de los estudiantes de Educación Secundaria sobre la enseñanza de la historia, a través del uso de las TIC y recursos digitales [Perceptions of secondary education students about the teaching of history through the use of ICT and digital resources]. Revista Electrónica Interuniversitaria de Formación Del Profesorado, 23(2), 67-79. https://doi.org/10.6018/reifop.417611

Moreno-Vera, J.-R., Monteagudo-Fernández, J., \& Antonio Rodríguez-Pérez, R. (2020). Instrumentos para la evaluación de las competencias históricas. La percepción del profesorado de Educación Secundaria en formación.[Instruments for the evaluation of historical competences [The perception of secondary education teachers in training]. In I. Aznar, M. P. Cáceres, J. A. Marín, \& A. J. Moreno (Eds.), Desafios de investigación educativa durante la pandemia COVID19 (pp. 301-310). Dykinson. https://repositorio.ipv.pt/bitstream/10400.19/6697/1/9788413771724\%20(1).pdf

Moya, M. del V., Hernández, J. R., Hernández, J. A., \& Cózar, R. (2011). Análisis de los estilos de aprendizaje y las TIC en la formación personal del alumnado universitario a través del cuestionario REATIC. [Analysis of learning styles and ICT in the personal training of university students through the REATIC questionnaire]. Revista de Investigación Educativa, 29(1), 137-156. http://hdl.handle.net/11162/14991

Muntaner, J. J., Pinya, C., \& Mut, B. (2020). El impacto de las metodologías activas en los resultados académicos [The impact of active methodologies on academic results]. Profesorado, Revista de Currículum y Formación Del Profesorado, 24(1), 96-114. https://doi.org/10.30827/profesorado.v24i1.8846

Murillo-Zamorano, L. R., López-Sánchez, J. Á., Godoy-Caballero, A. L., \& Bueno-Muñoz, C. (2021). Gamification and active learning in higher education: Is it possible to match digital society, academia and students' interests? International Journal of Educational Technology in Higher Education, 18, Article 15. https://doi.org/10.1186/s41239-021-00249-y

Orhan Göksün, D., \& Gürsoy, G. (2019). Comparing success and engagement in gamified learning experiences via Kahoot and Quizizz. Computers \& Education, 135, 15-29. https://doi.org/10.1016/j.compedu.2019.02.015

Pardo-Cueva, M., Chamba-Rueda, L. M., Higuerey Gómez, Á., \& Jaramillo-Campoverde, B. G. (2020). Las TIC y rendimiento académico en la educación superior: Una relación potenciada por el uso del Padlet [ICT and academic performance in higher education: A relationship enhanced by the use of Padlet]. Revista Ibérica de Sistemas e Tecnologias de Informaçao, E28, 934-944. http://www.risti.xyz/issues/ristie28.pdf

Pedaste, M., Mäeots, M., Siiman, L. A., de Jong, T., van Riesen, S. A. N., Kamp, E. T., Manoli, C. C., Zacharia, Z. C., \& Tsourlidaki, E. (2015). Phases of inquiry-based learning: Definitions and the inquiry cycle. Educational Research Review, 14, 47-61. https://doi.org/10.1016/j.edurev.2015.02.003

Pertegal-Felices, M. L., Jimeno-Morenilla, A., Sánchez-Romero, J. L., \& Mora-Mora, H. (2020). Comparison of the effects of the Kahoot tool on teacher training and computer engineering students for sustainable eucation. Sustainability, 12(11), Article 4778. https://doi.org/10.3390/su12114778

Punter, R. A., Meelissen, M. R. M., \& Glas, C. A. W. (2017). Gender differences in computer and information literacy: An exploration of the performances of girls and boys in ICILS 2013. European Educational Research Journal, 16(6), 762-780. https://doi.org/10.1177/1474904116672468 
Ramírez García, A., \& González Fernández, N. (2016). Competencia mediática del profesorado y del alumnado de educación obligatoria en España [Media competence of compulsory education teachers and students in Spain]. Comunicar, 49, 49-58. https://doi.org/10.3916/C49-2016-05

Rivero, P. (2011). Un estudio sobre la efectividad de la multimedia expositiva para el aprendizaje de la Historia [A study on the effectiveness of expository multimedia for the learning of history].

Enseñanza de Las Ciencias Sociales: Revista de Investigación, 10, 42-47. https://raco.cat/index.php/EnsenanzaCS/article/view/248891

Rivero, P. (2017). Procesos de gamificación en el aula de ciencias sociales [Gamification processes in the social sciences classroom]. Íber. Didáctica de Las Ciencias Sociales, Geografía e Historia., 86, 4-6. https://www.grao.com/es/producto/procesos-de-gamificacion-en-el-aula-de-ciencias-sociales

Roblizo, M. J., \& Cózar-Gutiérrez, R. (2015). Usos y competencias en TIC en los futuros maestros de educación infantil y primaria: hacia una alfabetización tecnológica real para docentes [ICT uses and competences in future early childhood and primary education teachers: Towards real technological literacy for teachers]. Píxel-Bit, Revista de Medios y Educación, 47, 23-39. https://doi.org/10.12795/pixelbit.2015.i47.02

Ruíz Giménez, M. C., Martínez Jiménez, R., García Martí, E., Pedrosa Ortega, C., \& Licerán Gutiérrez, A. (2019). ¿Es divertido aprender con Kahoot!?: la percepción de los estudiantes [Is it fun to learn with Kahoot!?: Students' perceptions]. Libro de Actas IN-RED 2019: V Congreso de Innovación Educativa y Docencia En Red, 26-39. https://doi.org/10.4995/INRED2019.2019.10368

Sabido-Codina, J., \& Albert Tarragona, J. M. (2020). Simultaneidad Histórica y Tratamiento Didáctico del Holocausto [Historical simultaneity and didactic treatment of the Holocaust]. Cuestiones Pedagógicas, 1(29), 37-48. https://doi.org/10.12795/cp.2020.i29.03

San Martín, Á., Peirats, J., \& López, M. (2015). Las tabletas y la gestión de los contenidos digitales en los centros escolares [Tablets and managing digital contents in schools]. Revista Iberoamericana de Educación, 67, 139-158. https://doi.org/10.35362/rie670225

Seixas, P., \& Morton, T. (2013). The Big Six historical thinking concepts. Nelson Education Ltd.

Shute, V. J. (2011). Stealth assessment in computer-based games to support learning. In E. Tobias \& J. D. Fletcher (Eds.), Computer games and instruction (pp. 503-523). IAP Information Age Publishing.

Subhash, S., \& Cudney, E. A. (2018). Gamified learning in higher education: A systematic review of the literature. Computers in Human Behavior, 87, 192-206. https://doi.org/10.1016/j.chb.2018.05.028

Talan, T., Doğan, Y., \& Batdı, V. (2020). Efficiency of digital and non-digital educational games: A comparative meta-analysis and a meta-thematic analysis. Journal of Research on Technology in Education, 52(4), 474-514. https://doi.org/10.1080/15391523.2020.1743798

Tan, D., Lin, A., Ganapathy, M., \& Kaur, M. (2018). Kahoot! It: Gamification in higher education. Pertanika Journal of Social Science and Humanities, 26(1), 565-582. http://www.pertanika.upm.edu.my/resources/files/Pertanika\%20PAPERS/JSSH\%20Vol.\%2026\%20(1 \%20Mar.\%202018/34\%20JSSH-2477-2017-3rdProof.pdf

Torres-Díaz, J. C., Duart, J. M., Gómez-Alvarado, H. F., Marín-Gutiérrez, I., \& Segarra-Faggioni, V. (2016). Internet use and academic success in university students. Comunicar, 24(48), 61-70. https://doi.org/10.3916/C48-2016-06

Tóth, Á., Lógó, P., \& Lógó, E. (2019). The effect of the Kahoot quiz on the student's results in the exam. Periodica Polytechnica Social and Management Sciences, 27(2), 173-179. https://doi.org/10.3311/PPso.12464

Turan, Z., \& Meral, E. (2018). Game-based versus to non-game-based: The impact of student response systems on students'achievements, engagements and test anxieties. Informatics in Education, 17(1), 105-116. https://doi.org/10.15388/infedu.2018.07

VanSledright, B. A. (2014). Assessing historical thinking and understanding. Innovative designs for new standards. Routledge.

Voet, M., \& De Wever, B. (2017). Preparing pre-service history teachers for organizing inquiry-based learning: The effects of an introductory training program. Teaching and Teacher Education, 63, 206217. https://doi.org/10.1016/j.tate.2016.12.019

Wang, A. I., Zhu, M., \& Sætre, R. (2016). The effect of digitizing and gamifying quizzing in classrooms. In T. Connolly \& L. Boyle (Eds.), Proceedings of the 10th European Conference on Games Based Learning (pp. 729-737). Academic Conferences and Publishing International Limited. http://hdl.handle.net/11250/2426374

Yau, H. K., \& Cheng, A. L. F. (2012). Gender difference of confidence in using technology. The Journal of Technology Studie, 38(2), 74-79. https://doi.org/10.21061/jots.v38i2.a.2 
Zichermann, G., \& Cunningham, C. (2011). Gamification by design: Implementing game mechanics in web and mobile apps. O'Reilly.

Corresponding author: Ramón Cózar-Gutiérrez, Ramon.Cozar@uclm.es

Copyright: Articles published in the Australasian Journal of Educational Technology (AJET) are available under Creative Commons Attribution Non-Commercial No Derivatives Licence (CC BY-NC-ND 4.0). Authors retain copyright in their work and grant AJET right of first publication under CC BY-NC-ND 4.0 .

Please cite as: Tirado-Olivares, S., Cózar-Gutiérrez, R., García-Olivares, R., \& González-Calero, J. A. (2021). Active learning in history teaching in higher education: The effect of inquiry-based learning and a student response system-based formative assessment in teacher training. Australasian Journal of Educational Technology, 37(5), 61-76. https://doi.org/10.14742/ajet.7087 